\title{
BCell MSPE
}

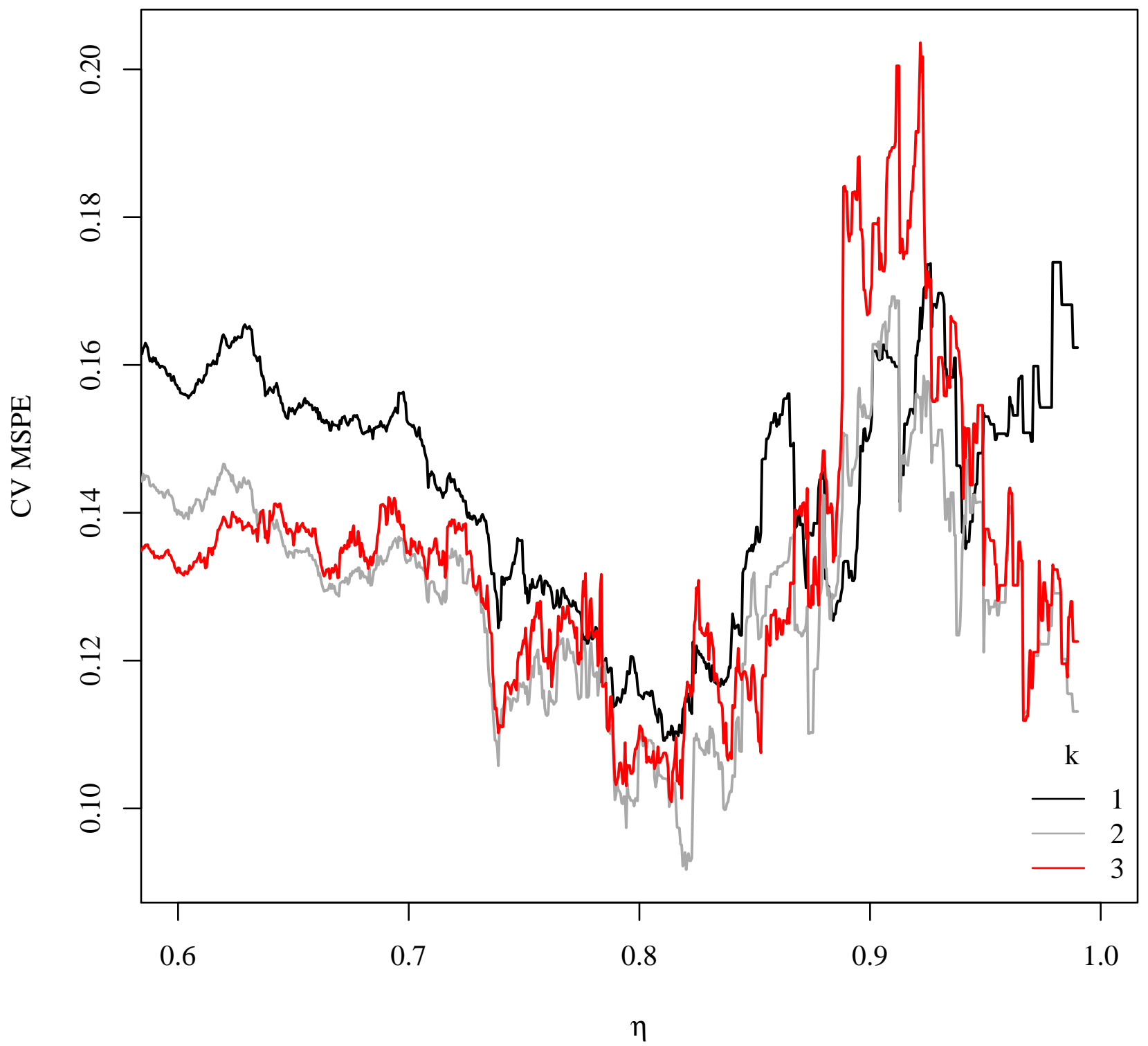

